\title{
Evidence on Delay in Sexual Initiation, Multiple Partnerships and Condom Use among Young People: Review of Caribbean HIV Behavioural Studies
}

\author{
CF Allen ${ }^{1}$, P Edwards ${ }^{2}$, F Gennari ${ }^{3}$, C Francis ${ }^{1}$, S Caffe ${ }^{3}$, E Boisson ${ }^{4}$, S Jones ${ }^{2}$, N Jack ${ }^{2}$
}

\begin{abstract}
Objective: To develop a Caribbean regional profile of youth sexual behaviour associated with risk of HIV.

Design and methods: A review of sexual behaviour surveys with youth aged 15-24 years was conducted as part of the Pan American Health Organization (PAHO) HIV Caribbean Office's Review and Gender Analysis of Caribbean HIV Behavioural and Seroprevalence Studies. Studies with internationally recommended indicators were prioritized. Studies were sought via database searches and contact with researchers and National AIDS Programmes.

Results: Inter-country comparisons and longitudinal analyses were limited by lack of uniformity in study age groups and indicators. Data were sufficient to identify the following among 15-24-year olds:

* More males than females report sexual intercourse before the age of 15 years.

* More than half of sexually active youth report sex before age 16 years.

* First sexual encounter is usually with someone older, with age differences larger for females.

* More males than females report multiple partnerships, with 20\%-76\% of males reporting this in the past year.

* Condom use varies widely, with no clear pattern by gender.

Conclusion: There are substantial levels of early sexual initiation, intergenerational sex among females and multiple partnerships among males, while condom use is inconsistent. Efforts to promote delay in sexual initiation, partner reduction and consistent condom use should be supplemented with initiatives against harmful gender norms, child abuse and transactional sex and skills to negotiate safe sex. Standardization of survey methods to facilitate cross-study comparisons should continue and encompass additional risk factors such as transactional sex, gender-based violence, drug use and HIV treatment adherence.
\end{abstract}

Key words: HIV, sexual behaviour, surveillance, youth

\section{Evidencias sobre la Demora en la Iniciación Sexual, las Parejas Múltiples, y el Uso del Condón entre los Jóvenes: Revisión de Estudios de Conducta en Relación con el VIH en el Caribe

\author{
CF Allen ${ }^{1}$, P Edwards ${ }^{2}$, F Gennari ${ }^{3}$, C Francis ${ }^{1}$, S Caffe ${ }^{3}$, E Boisson ${ }^{4}$, S Jones ${ }^{2}$, N Jack ${ }^{2}$
}

\begin{abstract}
RESUMEN
Objetivo: Desarrollar un perfil regional caribeño del comportamiento sexual de la juventud en relación con el riesgo de VIH.

Diseño y métodos: Se realizó una revisión de los estudios del comportamiento sexual de jóvenes entre 15 y 24 años, como parte del Estudio de la Oficina de VIH de la Organización Panamericana de la Salud (OPS) para el Caribe, y el Análisis de Género de los Estudios de Seroprevalencia y Conducta en relación con el VIH en el Caribe. Se le dio prioridad a los estudios con indicadores recomendados internacionalmente. Se obtuvieron estudios mediante búsquedas de bases de datos y contactos con los investigadores y los programas nacionales de SIDA.
\end{abstract}

From: ${ }^{1}$ Consultant to PAHO HIV Caribbean Office, Port-of-Spain, Trinidad and Tobago, ${ }^{2}$ PAHO HIV Caribbean Office, Port-of-Spain, Trinidad and

Tobago, ${ }^{3}$ Pan American Health Organization, Washington DC, USA, and

${ }^{4}$ Pan American Health Organization, Port-of-Spain, Trinidad and Tobago.
Correspondence: Dr Allen, PAHO HIV Caribbean Office, Port-of-Spain, Trinidad and Tobago. E-mail: allen.carolinef@gmail.com 
Resultados: Los análisis longitudinales y las comparaciones entre países estuvieron limitados por la falta de uniformidad en los grupos etarios y los indicadores de los estudios. Los datos fueron suficientes para identificar lo siguiente entre los jóvenes de 15 a 24 años de edad:

* Más varones que hembras reportaron relaciones sexuales antes de los 15 años de edad.

* Más de la mitad de los jóvenes sexualmente activos reportaron relaciones sexuales antes de los 16 años.

* El primer encuentro sexual suele ser con alguien de más edad, siendo las diferencias de edad mayores para las mujeres.

* Más varones que hembras reportaron relaciones de parejas múltiples; 20\%-76\% de los hombres reportaron este tipo de relación en el último año.

* El uso del condón varía ampliamente, sin un patrón claro por género.

Conclusión: Hay niveles considerables de iniciación sexual temprana, sexo intergeneracional entre las hembras, y múltiples parejas entre los varones, mientras que el uso del preservativo es inconsistente. Los esfuerzos por promover la demora en la iniciación sexual, la reducción de parejas, y el uso sistemático del condón deberían complementarse con las iniciativas contra las normas de género perjudiciales, el abuso infantil, el sexo transaccional, y las habilidades para negociar sexo seguro. La estandarización de los métodos de encuesta para facilitar las comparaciones transversales debe continuar y abarcar otros factores de riesgo, tales como el sexo transaccional, la violencia de género, el uso de drogas, y el cumplimiento con el tratamiento del VIH.

Palabras claves: VIH, vigilancia, comportamiento sexual, jóvenes

West Indian Med J 2013; 62 (4): 293

\section{INTRODUCTION}

It has been estimated that $50 \%$ of HIV transmission globally takes place in the age group 15-24 years. This demographic is key to HIV epidemiology, since frequency of sexual activity and partner turnover are high while many youth have limited skills to adopt safer sexual practices such as delay in sexual initiation, reduction in the number of sex partners and condom use (1). Among 15-24 year olds in most Caribbean countries, the number of females diagnosed with HIV exceeds the number of diagnosed males, in some countries several-fold, contributing to increasing "feminization" of the HIV epidemic, with females now estimated to account for $53 \%$ of people with HIV in the Caribbean (2) and suggesting gender-related differences in vulnerability.

Most quantitative HIV surveys in the Caribbean have been with youth (with varying age groups) or the general population (usually with the 25-49-year age group). Many of these have been used for national monitoring or reporting to international agencies but have not been published in peer reviewed literature or compared systematically to develop a Caribbean profile. The Pan American Health Organization (PAHO) HIV Caribbean Office (PHCO) commissioned a review to synthesize Caribbean HIV seroprevalence and behavioural studies, as part of a larger initiative to provide a regional epidemiological profile. This paper focusses on review results relating to the sexual behaviour of young people.

\section{METHODS}

The PHCO Review and Gender Analysis of Caribbean HIV Behavioural and Seroprevalence Studies prioritized studies with indicators recommended by international entities such as UNAIDS and the United States President's Emergency Plan for AIDS Relief (PEPFAR) and/or agreed by the UN General Assembly Special Session on HIV/AIDS (UNGASS). These indicators, which include age at first sex, multiple partnerships and condom use (3-7), are of agreed epidemiological importance, and their choice facilitated inter-country comparisons. Some other behavioural topics were also selected for review, namely transactional sex, gender-based violence, drug use, genital practices and HIV treatment adherence, which have been shown in a growing body of research to influence HIV risk (8-12). The review was carried out for several populations; in this paper we focus on young people, within the age group 15-24 years selected for attention in line with international recommendations. Gender analysis was carried out but is not reported in this paper.

Studies were accessed via searches on PubMed online database, the Caribbean Health Research Council Database of Caribbean HIV Research (13) and the HIV/AIDS Survey Indicators Database (14). Pan American Health Organization HIV Caribbean Office sent a letter to National AIDS Programmes (NAPs) requesting access to studies and selected Caribbean HIV researchers were contacted via e-mail. At the Caribbean HIV Conference in The Bahamas, in November 2011, flyers were handed out by PHCO staff and the consultant to participants to request that they provide relevant studies via e-mail. This literature review did not directly involve human subjects. The research protocol was approved by the Pan American Health Organization Ethics Review Committee (PAHOERC). 


\section{RESULTS}

Few studies were accessed from NAPs and via flyers handed out at the Caribbean HIV conference, so the review relied largely on databases and contact with researchers. Some studies were excluded because they did not cover the required age group (15-24 years) or use the selected indicators. Inter-country comparisons and longitudinal analyses were limited by lack of uniformity in study age groups and indicators.

Many Caribbean youth surveys with varying age groups have asked the question, "Have you ever had sex?" thus enabling the calculation of the percentages that have never had sex (primary abstinence). As shown in Fig. 1, in males reported abstinence, with averages across these countries being $27 \%$ for males and $48 \%$ for females (14-15).

\section{Age at first sex}

Caribbean surveys consistently report earlier age at first sex among males than females (16-23). In surveys among 15-24 year olds, about three times as many males as females in four Eastern Caribbean countries and Haiti reported sex before the age of 15 years (14-24) [Fig. 2]. Most young people do not report having sex by age 15 years; the highest percentage in studies among 15-24 year olds since 2005 was in Barbados, at $47 \%$ [data not disaggregated by sex] (25). However, of sexually active youth, most have sex by the legal age of con-

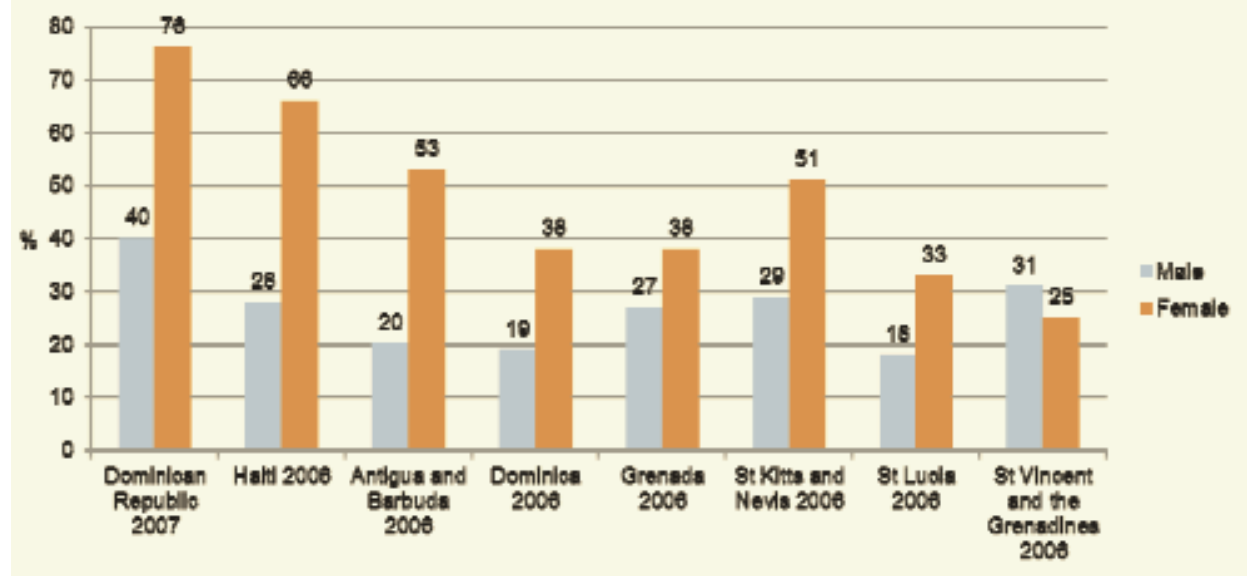

Fig. 1: Primary abstinence: percentages of young people aged 15-24 who report they have never had sex.

Sources: Dominican Republic and Haiti: HIV/AIDS Survey Indicators Database (MEASURE Evaluation) Organisation of Eastern Caribbean States (OECS) Behavioural Surveillance Surveys (CAREC 2007)

Haiti, the Dominican Republic and six Eastern Caribbean countries, levels of primary abstinence among 15-24-year olds ranged from 18 to $40 \%$ among males and $25 \%$ to $76 \%$ among females. In all but one country, more females than sent to sex [16 in most countries] $(16,17,25)$ with surveys among 15-24 year olds showing median ages of first sex of 15 for boys and 16 for girls $(15,16)$.

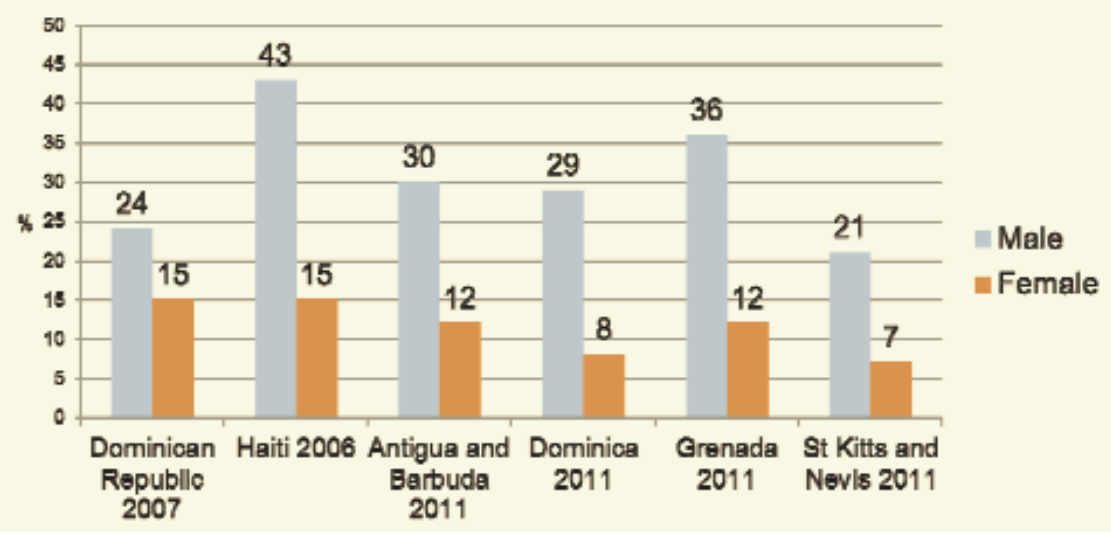

Fig. 2: Early sex: percentage of young people aged 15-24 years who report sexual intercourse before the age of 15 years.

Sources: Dominican Republic and Haiti: HIV/AIDS Survey Indicators Database (MEASURE Evaluation) Eastern Caribbean: OECS Knowledge, Attitudes, Beliefs and Practices surveys (OECS HIV/AIDS Programme Unit and Health Economics Unit, University of the West Indies) 


\section{Age mixing in sexual relationships}

The key indicator of age mixing recommended by UNAIDS is the percentage of women aged 15-19 years who have had sex with a man at least 10 years older than themselves in the last 12 months (7). In studies with this indicator, also termed intergenerational sex, it ranged from $4 \%$ in St Kitts and Nevis to $29 \%$ in Barbados [Fig. 3] (14, 26-31). Surveys indicate

\section{Multiple partnerships}

Caribbean surveys consistently find greater percentages of males than females reporting sex with more than one partner per time period $(14,17,21,24,27,41,42)$. Studies in four Eastern Caribbean countries show higher percentages of multiple partnerships among 20-24 year olds than among both

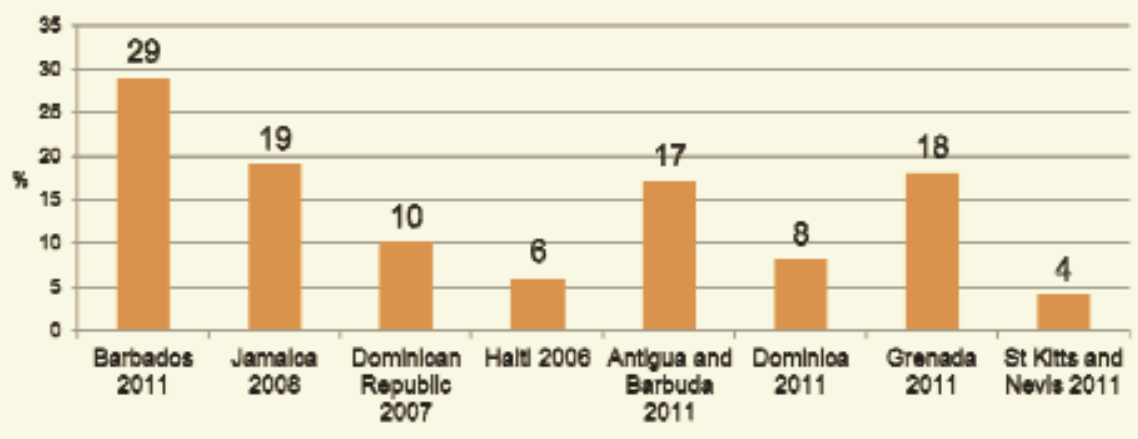

Fig. 3: Age mixing in sexual relationships: percentage of females aged 15-19 years who report they have had sex with a man at least 10 years older than themselves in the last 12 months.

Sources: Barbados: Transactional and Intergenerational Sex study (Perks et al, 2012); Jamaica: 2008 HIV/AIDS Knowledge, Attitudes, Beliefs and Practices Survey (Hope Enterprises); DR and Haiti: HIV/AIDS Survey Indicators Database (MEASURE Evaluation); OECS: Country reports from OECS Knowledge, Attitudes, Beliefs and Practices surveys (OECS HIV/AIDS Programme Unit and Health Economics Unit, University of the West Indies)

that most Caribbean youth have first sex with an older person, with the age difference being larger for girls than boys $(15,26,32,33)$. For instance, in a Tobago study with 10-24 year olds, on average the partners of boys were 1.2 years older and the partners of girls four years older (32). Research has suggested that transactional sex may explain sex between young people and older people (26, 34-36). Studies with varying youth age groups suggest substantial levels of forced sex, especially against girls and/or at first sex $(20,36-$ 40). Forced sex and unwanted sex have not been included in most surveys with 15-24 year olds. younger and older age groups $(15,24)$. In studies in the Dominican Republic and Haiti, fewer male 15-24 years olds than older men had multiple partners while the reverse age pattern applied to females (14). In all studies reviewed, less than half of females report multiple partners while in two Jamaican studies $(27,41)$ more than half of males report multiple partners in the past year. Figure 4 shows the most recent figures. Data from Jamaica show higher percentages of male and female youth with multiple partnerships in 2008 than 2004 (27).

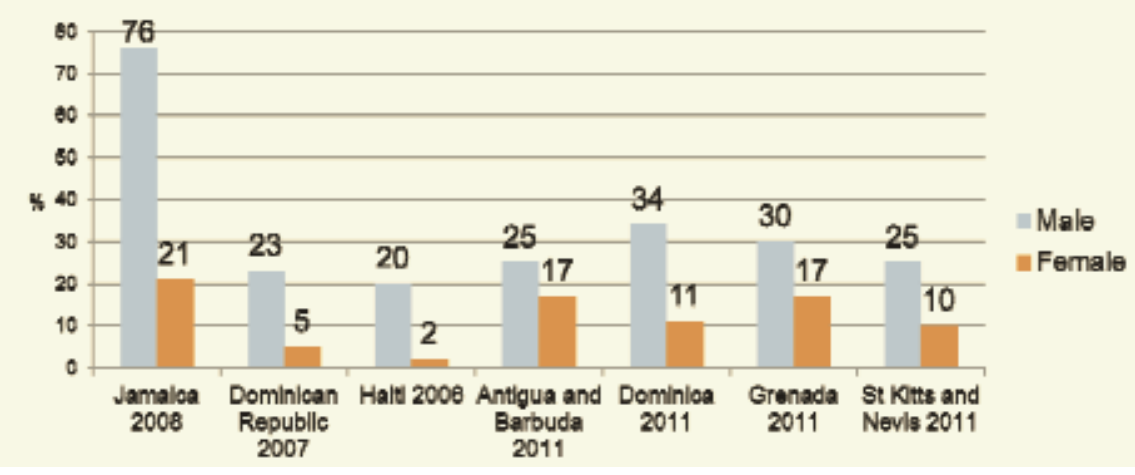

Fig. 4: Percentage of young people aged 15-24 who report they had sexual intercourse with more than one partner over the past 12 months

Sources: Jamaica: 2008 HIV/AIDS Knowledge, Attitudes, Beliefs and Practices Survey (Hope Enterprises); DR and Haiti: HIV/ AIDS Survey Indicators Database (MEASURE Evaluation); OECS: Country reports from OECS Knowledge, Attitudes, Beliefs and Practices surveys (OECS HIV/AIDS Programme Unit and Health Economics Unit, University of the West Indies) 


\section{Condom use}

Condom use at first sex among 15-24 year olds is an indicator recommended by UNAIDS (7). On this indicator, studies since 2005 give a range for males from $15 \%$ to $53 \%$ and for females from $15 \%$ to $78 \%(14,24)$ [Fig. 5]. In terms sexual activity $(50,51)$. The differences between males and females found in Caribbean HIV behavioural surveys, which rely predominantly on such interviews, may exaggerate the true extent of differences. However, the degree of consitency in the patterns found (except for condom use) is re-

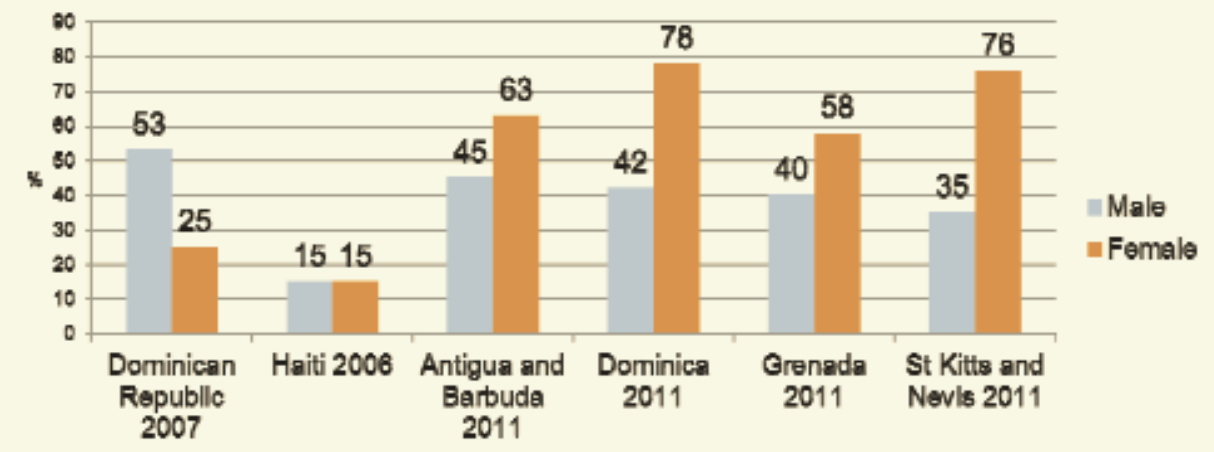

Fig. 5: Condom use at first sex: percentage of young people aged 15-24 years who reported they used a condom the first time they had sex, of those who ever had sex.

Sources: DR and Haiti: HIV/AIDS Survey Indicators Database (MEASURE Evaluation); OECS: Country reports from OECS Knowledge, Attitudes, Beliefs and Practices surveys (OECS HIV/AIDS Programme Unit and Health Economics Unit, University of the West Indies)

of condom use at last sex, the evidence suggests that condom use is higher among youth than older people, but there is no clear pattern in propensity of male versus female youth to use condoms (16, 17, 42-44). Longitudinal data from Jamaica show increases in condom use among males but not females (45).

\section{DISCUSSION}

With the exception of multi-country and longitudinal studies $(15,20,24,27,41,45)$, study methods vary. Therefore caution should be used in comparisons; in this review, general patterns are highlighted. Uniformity in sexual behaviour indicators has improved since previous reviews, $(16,17)$ but there remain many studies in which indicator construction appears not to have been influenced by the UNGASS, UNAIDS and PEPFAR recommendations, limiting the construction of a regional picture. A variety of age groups and other indicator components have been used in youth sexual behaviour studies and it is not clear whether the study designers considered balancing an approach tailored to national intervention priorities with maximizing the capacity for international comparisons. A few studies do not disaggregate data by gender $(25,46)$ : substantial differences between males and females suggest that such studies miss important opportunities to identify gender-related sexual behaviour patterns and thus target prevention interventions. Further capacity building and HIV behavioural surveillance system strengthening are recommended.

Social desirability bias has been shown in studies using structured face-to-face interviews on sexual behaviour (4749). Patterns of bias may be gender-related, with a cultural tendency for males to over-report and females to under-report markable, offering some external validation of the patterns. Results of such surveys should continue to be compared not only with each other but with studies using other methods, especially methods offering more privacy (self-completion) and qualitative methods, to improve the robustness of knowledge about sexual behaviour.

While the surveys reviewed suggest that some youth are not sexually active, sexual behaviour among those who are active gives cause for concern. Close to half of these young people have their first sexual experience below the legal age, and there are substantial levels of intergenerational sex among females and multiple partnerships among males, while condom use is inconsistent. As a point of comparison, a study across 34 European countries and Canada gave average prevalence of sexual intercourse by age 15 years of $29 \%$ among boys and 23\% among girls (52); our review found similar or higher rates among males and lower rates among girls. Existing sexual health promotion strategies that tend to focus on delay in sexual initiation (abstinence), reduction in partner numbers and condom use have had limited success (1). These strategies should be supplemented by initiatives against child abuse (36) and should also contest the gender norms and economic factors driving transactional sex (35, 53) and multiple partnerships, along with skills to negotiate safe sex and equitable relationships $(54,55)$. It is also clear that many youths need access to the full range of sexual and reproductive health services; restricted access due to the legal requirement of parental consent until the age of legal majority (18) should be addressed.

Standard indicators recommended by international agencies are not fully implemented and do not capture important risk/protective factors relating to HIV such as tran- 
sactional sex, gender-based violence, partner concurrency, drug use, genital practices and HIV treatment adherence. These are the subject of an emerging body of Caribbean research $(22,35,54-62)$. It is recommended that indicators related to these factors be standardized so that a more robust picture of the regional vulnerabilities of youth can emerge. There is also a need for operational and translational research to utilize these data and inform policy and service delivery strategies for quality care for young people.

\section{REFERENCES}

1. Ross D, Dick B, Ferguson J, eds. Preventing HIV/AIDS in young people: a systematic review of the evidence from developing countries. Technical Report Series. Geneva: World Health Organization; 2006.

2. UNAIDS. Keeping score III: The voice of the Caribbean people. Portof-Spain, Trinidad and Tobago: UNAIDS; 2011.

3. UNAIDS. Guidelines on construction of core indicators. 2010 Reporting on UNGASS. Geneva: UNAIDS; 2009.

4. Caribbean Health Research Council. Caribbean indicators and monitoring tools (CIMT) for monitoring and evaluating national AIDS programmes. St Augustine, Trinidad and Tobago: Caribbean Health Research Council; 2005.

5. The President's Emergency Plan for AIDS Relief. Indicators reference guide: indicators, reporting requirements, and guidelines. Washington, DC: PEPFAR; 2007.

6. The President's Emergency Plan for AIDS Relief. Next generation indicators reference guide. Washington, DC: PEPFAR; 2009.

7. UNAIDS. National AIDS programmes: a guide to monitoring and evaluation. Geneva: Joint United Nations Programme on HIV/AIDS; 2000.

8. Cohen M, Chen Y, McCauley M, Gamble T, Hosseinipour M, Kumarasamy $\mathrm{N}$ et al. Prevention of HIV-1 infection with early antiretroviral therapy. N Engl J Med 2011; 365: 493-505.

9. Myer L, Denny L, de Souza M, Wright TC, Kuhn L. Distinguishing the temporal association between women's intravaginal practices and risk of human immunodeficiency virus infection: a prospective study of South African women. Am J Epidemiol 2006; 163: 552-60.

10. Weiss HA, Halperin D, Bailey RC, Hayes RJ, Schmid G, Hankins CA. Male circumcision for HIV prevention: from evidence to action? AIDS 2008; 22: 567-74.

11. Silberschmidt M, Rasch V. Adolescent girls, illegal abortions and 'sugar-daddies' in Dar es Salaam: vulnerable victims and active social agents. Soc Sci Med 2001; 52: 1815-26.

12. Jewkes R, Dunkle K, Nduna M, Shai N. Intimate partner violence, relationship power inequity, and incidence of HIV infection in young women in South Africa: a cohort study. Lancet 2010; 376: 41-8.

13. Caribbean Health Research Council. Database of Caribbean HIV research. 2008 [cited 2012 March]; Available from: http://aidsresearch. chrc-caribbean.org/webpages/database_endnote.htm

14. MEASURE Evaluation. HIV/AIDS Survey Indicators Database. 2012 [cited 2012 March 5]; Available from: http://www.measuredhs. com/hivdata/

15. Ogunnaike-Cooke S, Kabore I, Bombereau G, Espeut D, O'Neil C, Hirnschall G. Behavioural surveillance surveys in six countries of the Organisation of Eastern Caribbean States (2005-2006). Port-of-Spain, Trinidad and Tobago: US Agency for International Development, Family Health International, Caribbean Epidemiology Centre and the Pan American Health Organisation; 2006.

16. Allen C, Samiel S, Burrell T, Hospedales C. HIV risk behaviour in the Caribbean among adults and young people. Conference on the Social History of Medicine and Public Health Policy in the Caribbean. Cave Hill, Barbados: The University of the West Indies; 2001.

17. Bombereau G. Systematic review related to HIV risk behaviours in the Caribbean among children, young adults and vulnerable populations. Port-of-Spain, Trinidad and Tobago: Caribbean Epidemiology Centre; 2007.
18. Centers for Disease Control and Prevention. Global School-Based Student Health Survey Fact Sheets. 2009 [cited 2012 January]. Available from: http://www.cdc.gov/gshs/countries/americas/index.htm

19. Blum R, Halcon L, Beuhring T, Pate EC-FS, Venema A. Adolescent health in the Caribbean: risk and protective factors. Am J Public Health 2003; 93: 456-60.

20. Blum R, Ireland M. Reducing risk, increasing protective factors: findings from the Caribbean Youth Health Survey. J Adolesc Health 2004; 35: $493-500$.

21. Allen C. Gender and the transmission of HIV in the Caribbean. The Society for Caribbean Studies Annual Conference Papers 2002; 3. Available from: http://www.caribbeanstudies.org.uk/papers/2002/ olv3p7.PDF

22. Kempadoo K, Dunn L. Factors that shape the initiation of early sexual activity among adolescent girls and boys: a study of three communities in Jamaica. Kingston, Jamaica: Centre for Gender and Development Studies, The University of the West Indies; 2001.

23. Kurtz SP, Douglas KG, Lugo Y. Sexual risks and concerns about AIDS among adolescents in Anguilla. AIDS Care 2005; 17 (Suppl 1): S3644.

24. Organisation of Eastern Caribbean States, Health Economics Unit, The University of the West Indies. Knowledge, Attitudes, Beliefs and Practices (KABP) Surveys on HIV/AIDS in Antigua and Barbuda, St Kitts and Nevis, Dominica and Grenada: Synthesized Report. Castries, St Lucia: HIV/AIDS Programme Unit, Organisation of Eastern Caribbean States; 2011.

25. Ministry of Education, Youth Affairs and Sports. Barbados National Youth KABP Survey on HIV. Bridgetown, Barbados: Ministry of Education, Youth Affairs and Sports; 2009.

26. Perks C, Drakes N, Hambleton IR, Kumar A, Quimby K, Patel R et al. Transactional and inter-generational sex with older men (TIGSex Survey): a survey in Barbadian girls aged 15-19. Presented at the $3^{\text {rd }}$ European Public Health Conference, Amsterdam, The Netherlands, November 10-13, 2010.

27. Hope Enterprises. 2008 HIV/AIDS Knowledge Attitudes and Behavior Survey, Jamaica. Kingston, Jamaica: KfW, PANCAP and Constella Group; 2008.

28. Organisation of Eastern Caribbean States, Health Economics Unit. Knowledge, attitudes, beliefs and practices (KABP) surveys on HIV/ AIDS in four OECS member states: Dominica. Castries, St Lucia: OECS HIV/AIDS Programme Unit; 2011.

29. Organisation of Eastern Caribbean States, Health Economics Unit. Knowledge, attitudes, beliefs and practices (KABP) Surveys on HIV/AIDS in four OECS member states: Grenada. Castries, St Lucia: OECS HIV/AIDS Programme Unit; 2011.

30. Organisation of Eastern Caribbean States, Health Economics Unit. Knowledge, attitudes, beliefs and practices (KABP) surveys on HIV/AIDS in four OECS member states: Antigua and Barbuda. Castries, St Lucia: OECS HIV/AIDS Programme Unit; 2011.

31. Organisation of Eastern Caribbean States, Health Economics Unit. Knowledge, attitudes, beliefs and practices (KABP) surveys on HIV/AIDS in four OECS member states: St. Kitts and Nevis. Castries, St Lucia: OECS HIV/AIDS Programme Unit; 2011.

32. Allen C, Martinez DD, Wagner U, McLetchie K, Washington AD, Chapman-Smith T et al. The sexual behaviour of youth in Tobago. A report on the development of a health promotion project. West Indian Med J 2002; 51: 197-9.

33. Pan American Health Organization. Quantitative evaluation of the KAPB of school aged youth in Bartica to HIV/AIDS. Georgetown, Guyana: Pan American Health Organization; 2000.

34. Hawkins K, Joseph J, Longfield K, Best T. 'Money make the nookie go 'round': Young women and sexual relationships in two locations in Trinidad. Port of Spain: Options Consulting Limited and Population Services International; 2007.

35. Barrow C. Adolescent girls, sexuality and HIV/AIDS in Barbados: the case for reconfiguring research and policy. Caribbean Journal of Social Work 2006; 5: 62-80.

36. Jones AD, Jemmott ET. Child sexual abuse in the Eastern Caribbean: perceptions of, attitudes to, and opinions on child sexual abuse in the 
Eastern Caribbean. Action for Children, University of Huddersfield, UNICEF/UNIFEM; 2010.

37. Halcon L, Blum R, Beuhring T, Pate E, Campell-Forrester S, Venema A. Adolescent health in the Caribbean: a regional portrait. Am J Public Health 2003; 93: 1851-7.

38. Ohene S, Ireland M, Blum R. The clustering of risk behaviors among Caribbean youth. Maternal Child Health J 2005; 9: 91-100.

39. George C, Alary M, Otis J. Correlates of sexual activity and inconsistent condom use among high school girls in Dominica. West Indian Med J 2007; 56: 433-8.

40. Baumgartner J, Waszak Geary C, Tucker H, Wedderburn M. The influence of early sexual debut and sexual violence on adolescent pregnancy: a matched case-control study in Jamaica. Int Perspect Sex Reprod Health 2009; 31: 21-8.

41. Hope Enterprises Ltd. Report of national knowledge, attitudes, behaviour and practices (KABP) survey year 2004. Kingston, Jamaica: Hope Enterprises Ltd; 2004.

42. Bombereau G, Allen C. Social and cultural factors driving the HIV epidemic in the Caribbean: a literature review. St Augustine, Trinidad and Tobago: Caribbean Health Research Council; 2008. Available from: http://aidsresearch.chrc-caribbean.org/webpages/lit_review.htm

43. Population Services International. Trinidad and Tobago (2009): HIV/AIDS TRAC Study evaluating condom use among sexually active youth 16-26 years in Tobago: round 1. Washington, DC: Population Services International; 2009.

44. Population Services International. HIV/AIDS TRaC Study evaluating condom use among sexually active youth $16-24$ years in St. Lucia: round 1. Washington DC: Population Services International; 2010.

45. Norman LR, Figueroa JP, Wedderburn M, Byfield L, Bourne D, Gebre Y. Trends in HIV risk perception, condom use and sexual history among Jamaican youth, 1996-2004. Int J Adolesc Med Health 2007; 19: 199-207.

46. Barbados Youth Affairs Department. Report on the National Youth KABP Survey on HIV-AIDS 2005-2006. Bridgetown, Barbados: National HIV/AIDS Commission; 2006.

47. Allen CF, Lees SS, Desmond N, Der G, Chiduo B, Hambleton IR et al. Validity of coital diaries in a feasibility study for the Microbicides Development Programme trial among women at high risk of HIV/AIDS in Mwanza, Tanzania. Sex Transm Infect 2007; 83: 490-7.

48. Lees S, Cook C, Vallely A, Desmond N, Allen C, Kiro K et al. Comparison of sexual behaviour data collected using a coital diary and a clinic-based interview during a microbicide pilot study in Mwanza, Tanzania. Sex Trans Dis 2010; 37: 497-501.

49. Gregson $\mathrm{S}$, Mushati $\mathrm{P}$, White P. Informal confidential voting interview methods and temporal changes in reported sexual risk behaviour for HIV transmission in sub-Saharan Africa. Sex Transm Inf 2004; 80 (Suppl II): ii36-42.
50. Chevannes B. Gender and adult sexuality. In: Mohammed P, ed. Gendered Realities. Kingston, Jamaica: The University of the West Indies Press; 2002.

51. Plummer ML, Ross DA, Wight D, Changalucha J, Mshana G, Wamoyi J. "A bit more truthful": the validity of adolescent sexual behaviour data collected in rural northern Tanzania using five methods. Sex Transm Infect 2004; 80 (Suppl II): ii49-ii56.

52. Currie C, Zanotti C, Morgan A, Currie D, de Looze M, Roberts C et al, eds. Social determinants of health and well-being among young people: Health Behaviour in School Aged Children (HBSC) Study: international report from the 2009/2010 survey. Health Policy for Children and Adolescents. Copenhagen: World Health Organization Regional Office for Europe; 2012.

53. Barrow C. Children and social policy in Barbados: the unfinished agenda of child abuse. Caribbean Journal of Social Work 2003; 2: 36 53.

54. Allen C. Intersections between HIV/AIDS and violence against women: research to develop pilot projects in Barbados and Dominica. J Eastern Caribbean Studies 2011; 36.

55. Allen C, Odlum Y. Violence against women and HIV in the Caribbean: an exploration of linkages and interventions. Presented at the Caribbean HIV Conference, Atlantis Hotel, The Bahamas, November 18-21, 2011.

56. Day M, Devieux JG, Reid SD, Jones DJ, Meharris J, Malow R. HIV risk behaviours among homeless out-of-treatment non-injecting drug users in two Caribbean states. American Black Nursing Journal 2004: $121-6$.

57. Day M. Behavioural and HIV sero-prevalence study of non-injection homeless and poor crack cocaine users in Saint Lucia. Castries, St Lucia: The Caribbean Alcohol and Drug Research Institute; 2009.

58. Allen C, Thomas-Purcell K. Strengthening the evidence base on youth sexual and reproductive health and rights in the Eastern Caribbean: final report. Bridgetown, Barbados: United Nations Population Fund; 2012.

59. Halperin DT. Dry sex practices and HIV infection in the Dominican Republic and Haiti. Sex Trans Infect 1999; 75: 445-6.

60. Figueroa J, Jones Cooper C. Attitudes towards male circumcision among attendees at a sexually transmitted infection clinic. West Indian Med J 2010; 59: 351-5.

61. Brito MO, Caso LM, Balbuena H, Bailey RC. Acceptability of male circumcision for the prevention of HIV/AIDS in the Dominican Republic. PLoS ONE 2009; 4: 1-6.

62. Allen C, Simon Y, Edwards J, Simeon D. Adherence to antiretroviral therapy by people accessing services from non-governmental HIV support organisations in three Caribbean countries. West Indian Med J 2011; 60: 269-75. 